\title{
MORAL Y DERECHO EN EL PENSAMIENTO DE HOBBES
}

\begin{abstract}
Concerning the Thoughts of man... the Originall of them all, is that which we call Sense; (For there is no conception in a mans mind, which hath not a first, totally or by parts, been begotten upon the organs of Sense.)
\end{abstract}

(Leviathan, I, 1).

Sumario: 1) Hobbes en el pensamiento moral inglés. 2) Ley Natural y Derecho Natural. 3) Idea del Hombre. 4) Idea de la Sociedad. 5) Concepción Metafísica. 6) Ética: $a$. La conciencia. b. Bien y mal; justo $\mathrm{e}$ injusto. $c$. El interés como consejero moral. $d$. La justicia. e. La caridad. f. La libertad. g. La religión. h. El utilitarismo. 7) Comentario. 8) Bibliografía.

\section{1) Hobbes en el pensamiento moral inglés}

La ética inglesa es casi un descubrimiento en las investigacaiones francesas y alemanas de fines del siglo pasado y comienzos del actual. En Francia es Georges Lyon quien, a fines del xix, presenta un excelente estudio sobre la obra de Hobbes y se precia de tratar, por vez primera, otras obras inglesas importantes. ${ }^{1}$ En esta obra y en relación con nuestro trabajo es particularmente interesante el capítulo Ix, titulado "Moral". Wundt reconoce que: "Especialmente la filosofía moral inglesa, antiguamente poco conocida en Alemania, ha sido para mí de un extraordinario valor". ${ }^{2}$

Sin embargo parece que estos intentos de adentrarse en el pensamiento ético inglés, no fueron del todo afortunados. Pogson Smith, uno dè los más serios estudiosos del pensamiento de Hobbes, dice que los investigadores alemanes se han acercado al estudio de Hobbes

with perhaps more than their usual carcless audacity of assumption. 3

El investigador Sorley ${ }^{4}$ critica el intento de Kuno Fisher de relacionar la filosofía de Bacon con la de Hobbes, intento que vemos repetirse en la Historia de la Ética del español Navarro.

1 A. Lyon, La Philosophie de Hobbes. París, Alcan, 1899.

2 Wundt, Guillermo. Etica: Una investigación de los hechos y leyes de la vida moral. Trad. de Fermín Herrero Brahillo, 3 vols. Madrid, Daniel Jorro editor, prol. pág. 3.

3 Ensayo de W. G. Pogson Smith en la edición de Oxford del Leviathan, 1929.

4 Sorley, W. R., History of English Philosophy. 
Dice Navarro:

Lo que habia sido para Bacon asunto de hipótesis, supuestos y afirmaciones sueltas y desligadas se convierten en el discípulo en elementos integrantes de una concepción precisa, recortada y expuesta en la forma rigurosa de las ciencias matemáticas.5

Advierte Vörlander ${ }^{6}$ que el estudio de Hobbes, al menos en Alemania, había aumentado nuevamente por los trabajos de Fernando de Tönnies, quien editó varias obras de Hobbes según el manuscrito original.7.8 Los Elements of Law natural and politic, que Hobbes escribe en 1640 como defensa de la corona amenazada, no son editados hasta diez años más tarde con título diferente y precisamente es Tönnies quien, en 1889 , lo edita en su forma original.9 La edición más completa hasta ahora es la de Molesworth. ${ }^{10}$ La muerte impidió a Pogson Smith publicar su trabajo exhaustivo acerca de la posición de Hobbes en la historia del pensamiento europeo. ${ }^{11}$ Nos queda su valioso ensayo en relación con el tema que nos ocupa. ${ }^{12}$ Es interesante notar la influencia que ha ejercido Hobbes a través de la traducción española del Leviatán en nuestro pensamiento político y moral. La edición más reciente es la de 1940.13 Nos atrevemos a afirmar, sin embargo, aunque la influencia de Hobbes se nota en el predio político, que también se siente en las concepciones éticas de algunos de nuestros pensadores. $\mathrm{Y}$ es que en muchas de nuestras universidades latinoamericanas no se le ha dado la debida importancia al estudio de la ética, lo que hace difícil desenmarañar adecuadamente el pensamiento ético de Hobbes para mostrar sus falacias. En filosofía se ha descuidado el estudio de la ética, con el consiguiente resultado de que los estudiantes se encontraban indefensos ante el magnífico estilo y la sofística argumentación del creador del Leviathan. Se entra de lleno en la lectura de Hobbes no sólo sin la debida preparación de cursos de ética general o ética inglesa en particular, sino sin una concepción adecuada del momento histórico en que surge Hobbes y que en muchos aspectos explica ciertas fases y características de su doctrina. Recuerda Sánchez Sarto, traductor español del Leviatán, una obra de Leo Strauss traducida al inglés en $193^{14}$ y que es, en realidad, uno de los mejores estu-

5 Historia de la ética.

6 Vörlander, Historia de la filosofía, tomo II, pág. 24.

7 F. Tönnies, Hobbes, Leben und Lehre, 1896.

8 Idem, traducción de E. Imaz en la Revista de Occidente.

9 Ver para más datos la bibliografía que da Vörlander en su Historia de la filosofia.

10 Obras completas en latín e inglés, editadas por Sir William Molesworth.

11 Ver Prólogo y Ensayo en la ediciòn.de Oxford, 1929, del Leviathan.

12 Idem, Pogson Smith, The Philosophy of Hobbes.

13 Hobbes, Leviatán, trad. de Manuel Sánchez Sarto, Fondo de Cultura Económica, México, $194^{\circ}$.

14 The Political Philosophy of Thomas Hobbes trad. al inglés del manuscrito inédito 
dios de la filosofía política de Thomas Hobbes que se hayan hecho hasta ahora.

Al final de este trabajo presentamos una lista más completa de las ediciones de las obras de Hobbes, así como de los principales trabajos en torno al autor del Leviathan.

Hobbes escribió y estudió hasta edad muy avanzada. Por cierto que no fue sino hasta los treinta años cuando pudo suplir los defectos de su primera educación por medio de estudios clásicos que le permitieron, a los cuarenta, escribir en latín. Fue esto, quizás, lo que llevó a decir que si hubiera leído y estudiado tanto como otros hombres no sabría más que esos mismos hombres: "if he had read as much as other men, he should have knowne no more than other man".15

Para el pensamiento de Hobbes se han señalado como importantes algunas partes de su trabajo De,Corpore, que comprende su lógica, su primera filosofía y su filosofía de la naturaleza, y que se presenta en agresiva actitud contra la metafísica teológica; pero su fama descansa en tres libros:

Elements of Law,

Philosophical Rudiments concerning Government and Society (versión inglesa de la obra $D e$ Cive),

y Leviathan.

El primero viene a ser una especie de anticipo donde apenas se esquematiza la que será luego su audaz teoría. De Cive, Philosophical Rudiments concerning Government and Society, presenta el pensamiento político. Dice que en este libro se encontrarán los deberes de los hombres, primero como hombres, luego como súbditos y por último como cristianos. ${ }^{16}$ Hobbes trata de demostrar: ${ }^{17}$

r) Que el estado del hombre donde no existe la sociedad civil, estado que puede llamarse propiamente de naturaleza, es únicamente una guerra de todos contra todos; ${ }^{18}$ que en esa guerra todos los hombres tienen el mismo derecho a todas las cosas.

2) Todos los hombres, en cuanto comprenden esta situación de guerra, desean, y su misma naturaleza los obliga, liberarse de esa situación miserable. Pero esto no puede conseguirse sin un contrato por medio del cual todos depongan ese derecho que tienen a todas las cosas. Luego explica cuál es la naturaleza del contrato. Cómo y de qué manera el derecho de uno puede ser transferido a otro para hacer los contratos válidos; además, qué derechos y a quiénes necesariamente

alemán por Elsa M. Sinclair. Prólogo del profesor Ernest Baker, Clarendon Press, Oxford, 1946 .

15 Citado por Aubrey, Brief Lives, pág. 349.

16 Philosophical Rudiments concerning Government and Society, Preface XI.

17 Ver idem, Preface to the Reader.

$18 \mathrm{~A}$ war of all against all. 
se han de conceder para poder establecer la paz. Es decir, aquellos dictados de la razón que pueden propiamente llamarse leyes naturales. Todo esto en la primera parte, titulada Libertad.

3) Luego se refiere al Estado. Explica, basado en lo anterior, qué es un gobierno civil y cuál el poder supremo en este gobierno. Las diversas clases de gobierno, los medios que utilizan para constituirse y qué derechos los hombres particulares deben transferir al poder supremo, para constituir este gobierno, ya sea un hombre o una asamblea de hombres. Sólo así puede surgir el gobierno civil. De otra manera, los derechos de la guerra - los derechos de todos los hombres a todas las cosas - persisten. Explica la naturaleza de la ley y el pecado; distingue ley, consejo y pacto de lo que ha llamado derecho. Todo esto bajo el título de Gobierno o Dominio.

4) En la última parte se refiere al papel de la religión en el Estado y la denomina Religión. Pero su punto de vista completo de la vida y el orden social están en el Leviathan. El nombre, tomado del Libro de Job, es del animal "al que ninguno se parece", y significa el Estado meramente civil, desligado de la Iglesia, que también se encarga de la educación y debe laicizar las universidades.

La carátula del Leviathan, escribe Sorley, ${ }^{19}$ muestra magnificamente su propósito y sentido. La parte superior tiene al fondo una ciudad amurallada con iglesias de altas torres; tras de la ciudad el campo se prolonga hasta una colina de la cual surge un hombre hasta la cintura; tiene una corona en su cabeza; su mano derecha esgrime una espada y su izquierda un báculo de obispo; su cota de mallas es una multitud de figuras humanas con las caras vueltas hacia él, en forma suplicatoria; en la parte inferior están representados de uno y otro lado un castillo y una iglesia, una corona y una mitra, un cañón y la luz del relámpago, las armas para la guerra y las razones o métodos del argumento, un campo de batalla y una disputa en las escuelas. Sobre todo esto campea la leyenda: Non est potestas super terram quae comparetur ei. Éste es el designio "of that mortal God", cuya generación y poder trató de Hobḅes de describir. El Leviathan está dividido en cuatro partes, que tratan del Hombre, del Estado, del Estado Cristiano y del Reino de las Tinieblas.

1) Estado de naturaleza, ley natural y derecho natural. Su idea de la ley natural y el derecho natural

Es en el concepto de naturaleza donde hemos de encontrar mucho de

19 Sorley, English Philosophy, pág. 60. 
lo esencial que fundamenta el pensamiento ético de Hobbes. Advierte Litt 20 "que el, concepto de 'naturaleza'", que para la perpleja reflexión ética del Renacimiento sirvió de estrella orientadora, era tan multívoco que lo hacía impropio para ser clave de la vida moral.

El pensar renacentista llegó a atajar esta dificultad, y en forma que parecía mucho más segura y hacedera que la ofrecida por Grocio. La naturaleza habia abierto al hombre pensante los últimos secretos de una región suya, y resultaba que la acción de sus fuerzas obedecía a unas leyes que se revelaban idénticas a la regla inmanente de la razón humana. Los investigadores de la naturaleza, durante el Renacimiento, se percataron con ojos de asombro de que "la naturaleza está escrita en lenguaje matemático".

Dice Litt:

Aquellas relaciones que el espiritu podia determinar con infalibilidad, al parecer porque se referían a figuras que él mismo construía, es decir, porque eran creación del propio espiritu, reaparecen sorprendentemente en el juego de las fuerzas naturales. La ley más profunda de la razón parecía coincidir con la ley en que los cuerpos obedecían en sus movimientos. Se encontraba, en la forma más perfecta, aquello que el espíritu buscaba luego de haberse emancipado de la objetividad de la interpretación medieval de la existencia: una verdad tan cierta como sólida, pero que no viene de arriba, de fuera, que no había sido impuesta a la ignorancia humana mediante una revelación autoritaria, sino que se asienta en la naturaleza misma del espíritu humano y, por ello, se manifiesta a los ojos de la razón con la más clara evidencia. En el interior del hombre se encontraba la instancia objetiva que prometía la ansiada claridad y certeza. INunca habia dado aquel "lumen naturale" una prueba más certera de su vigencia cósmica!

Y perdónesenos lo extenso de la cita, pero en esta descripción de Litt encontramos el espíritu que prevalecía al hacer su aparición el pensamiento de Hobbes. Por eso una ética que trabaja con este concepto de naturaleza va a tratar de encontrar la solución a sus problemas y el método para su estudio e investigación en los principios de las ciencias matemáticas naturales.

\section{2) Ley Natural y Derecho Natural}

Es menester, afirma Hobbes, distinguir entre ley natural y derecho natural. Por el momento se puede afirmar que Derecho Natural es la libertad que tiene cada quien para emplear su poder en la forma que considere más conveniente para su conservación. La Ley Natural es la norma por medio de la cual se evita todo aquello que puede tener consecuencias perjudiciales pära el individuo. La ley viene a ser el límite del derecho: difieren el uno del otro como la libertad difiere de la obligación. ${ }^{21}$

Por la palabra derecho no hay que entender más que esa libertad que

20 T. Litt, La ética moderna, traducción de E. fmaz, Revista de Occidente, 1932, pág. 37.

21 Leviathan, Of Man, c. XIV. 
todo hombre tiene de hacer uso de facultades naturales de acuerdo con la recta razón. De ahí que el primer fundamento del derecho natural sea éste: que todo hombre tiene en sí la voluntad de proteger su vida y sus miembros.

Neither by the word right is anything else signified than that liberty which every man hath to make use of his natural faculties according to right reason. Therefore the first foundation of natural right is this: that every man as much as in him lies endeavour to protect his life and members.22

A right to the end gives also a right to the means. Since every man hath a right to preserve himself, he must also be allowed a right to use all the means and do all the actions without which he cannot preserve himself.23

By the right of nature every man is judge of the means which tend to his preservation.24

By right of nature all men have equal rights to all things.25

In the state of nature profit is the measure of right.26

The right of all to all is unprofitable. For although any man might say of everything this is mine yet could he not enjoy it, by reason of his neighbour, who having equal right and equal power pretend the same thing to be his.27

El derecho de naturaleza, afirmará Hobbes en el Leviathan, lo que los escritores llaman comúnmente ius naturale, es la libertad que cada hombre tiene de usar su propio poder para la conservación de su propia naturaleza, es decir, de su propia vida; y así pues, para hacer todo aquello que su propio juicio y razón consideren como los medios más aptos para lograr ese fin. ${ }^{28}$

Ley de naturaleza (lex naturalis) es un precepto o norma general, establecida por la razón, en virtud de la cual se prohibe a un hombre hacer lo que puede destruir su vida o privarle de los medios de conservarla; o bien, omitir aquello mediante lo cual piensa que puede quedar su vida mejor preservada. Aunque quienes se ocupan de estas cuestiones acostumbran confundir ius y lex, derecho y ley, precisa distinguir estos términos, porque el derecho consiste en la libertad de hacer o de omitir, mientras que la ley determina y obliga a una de esas dos cosas. Así, la ley y el derecho difieren tanto como la obligación y la libertad, que son incompatibles cuando se refieren a una misma materia. ${ }^{29} \mathrm{El}$ primer principio de la ley natural es: "hay que buscar la paz",30 y de ahí se deriva: "Para obtener la paz es necesario renunciar al derecho absoluto que tenemos sobre todas las cosas". ${ }^{31}$ Ésta es la segunda ley natural.

22 Hobbes, Philosophical Rudiments, c. I-7. The definition of right.

23 Hobbes, Philosophical Rudiments, c. I-8.

24 Idem, id., c. I-9.

25 Idem, id., c. I-10.

26 Idem, id., c. I-10.

27 Idem, id., c. I-11, pág. 11.

28 Leviathan, c. XIV.

29 Leviathan, c. XIV.

$30 \mathrm{De}$ Civ. lib. I, C. II, 1.

31 Id. ib., III. 
$\mathrm{Y}$ es necesario el sacrificio personal. Recuerda el Evangelio: "No hagas a otro aquello que no quieras te hagan a ti." 32

No es la ley divina que proclaman los teólogos. No hay voluntad alguna a la cual deba someterse el hombre. No es la ley social y política que presupone el estado organizado. No es la ley metafísica; nuestro método nos impide rebasar la esfera de los deseos que mueven el corazón humano. Esta ley natural está íntimamente relacionada con el derecho natural. "La ley natural es una dictada por la recta razón concerniente a lo que se debe hacer u omitir en vista a salvaguardar nuestra vida." 33

La Ley de la Naturaleza obliga siempre y sobre todo en el fuero interno o conciencia, no siempre en el fuero externo. ${ }^{34}$

- La lex naturalis tanto como el ius naturale, tienen un sentido egoísta en su referencia. La lex naturalis es:

A precept or general rule, found out by which a man is forbidden to do that which, is destructive of his life, or taketh away the means of preserving the same, and to omit that by which he thinketh it may be best preserved.

$\mathrm{Y}$ el ius naturale se presenta como: "The liberty each man hath to use his own power, as he will himself, for the preservation of his own life." Es decir, que mientras una afirma una libertad, la otra impone ina obligación. Pero acerca de qué se permite y a qué se obliga, la contestación será siempre: la preservación del individuo. Está permitido todo aquello por medio de lo cual podamos preservar y proteger nuestra vida. Sólo estamos obligados a aquello que redunda en la conservación de nuestra vida. Ya veremos hacia dónde conducirá tal principio en una teoría de la acción que pretenda regular la actividad vital de la criatura. ${ }^{35}$

Se define la ley natural como el consentimiento del género humano. La ley natural es el orden del derecho de razón sobre las cosas que favorecen u obstaculizan nuestra conservación. ¿¿Cuál es el derecho de razón? Es la razón particular de cada uno. La violación de las leyes de la naturaleza no es otra cosa que un razonamiento falso. ${ }^{36}$

La ley de la naturaleza es el dictado de la recta razón cuando discurre acerca de aquellas cosas que se deben hacer $\mathbf{u}$ omitir para la preservación y desarrollo de nuestra vida.

Pero es bueno recordar lo que entiende Hobbes por recta razón - "right reason"-, y que él se preocupa por definir cuidadosamente. ${ }^{37}$

Por recta razón en el estado natural del hombre no se debe entender una

32 Leviathan, of Man, c. XV.

33 Philosophical Rudiments, c. II. pág. 1.

34 Idem, c. III, párrafo 27.

35 De Civ. imperium, c. XIV, III, lex enim vinculum, ius libertas est.

36 Hobbes, Philosophical Rudiments, c. II.

37 Ver nota en Rudiments of Philosophy, c. II, 2. 
infalible facultad, sino el acto de razonar, o sea ese movimiento peculiar por el que cada hombre pesa los actos que pueden redundar en beneficio o perjuicio; justicia, gratitud, etc., están dentro de las leyes de la naturaleza de Hobbes; pero su autoridad no es absoluta; está condicionada por la disposición que tengan otros hombres para obedecerlas y esto requiere un acuerdo de voluntades: un contrato.

Se puede renunciar a estos derechos de dos maneras: por simple renunciación o por traslación. Según la primera fórmula se renunciaría simplemente a un determinado derecho. La segunda fórmula consiste sencillamente en la no resistencia. ${ }^{38} \mathrm{La}$ traslación mutua de un derecho entre dos o más personas se llama contrato y la promesa de aquellos que contratan es el pacto del contrato. ${ }^{39}$

Definition of contract and covenant: 40

But the act or two or more, mutually conveying their rights, is called a contract. But in every contract, either both parties instantly perform what they contract for, in so much as there is no trust had from either to other; or the one performs, the other is trusted; or neither perform. Where both parties perform presently there the contract is ended as soon as it is performed. But where there is credit given, either to one or both, there the party trusted promiseth after performance; and this kind of promise is called a covenant.

Covenants in the state of nature are in vain and of none effect: not so in civil government.41

La tercera ley de la naturaleza es que es necesario observar las convenciones. Si los hombres han renunciado a sus derechos por obtener la paz esta convención será vana si los pactos no se hacen inviolables. ${ }^{42}$

Si los pactos que resultan del consentimiento mutuo son obligatorios ¿se dirá lo mismo de pactos impuestos por la fuerza? La promesa hecha a un ladrón bajo amenaza de muerte, ‘es obligatoria? Hobbes dice que si. ${ }^{43}$

Hay casos en los cuales un pacto puede ser invalidado.44

Como advierte Janet ${ }^{45}$ ésta es la moral natural.46 No es la ley civil la que fija los artículos de la ley natural: es la razón; es la sola razón la que declara al hombre que debe buscar la paz y de este principio deducir todos los preceptos contenidos en el Decálogo ${ }^{47}$ y en el sentido común. La

38 Hobbes, Leviathan, Of Man, c. XIV.

39 Hobbes, Philosophical Rudiments; c. II, IX.

40 Idem, c. II, pág. 20.

41 ldem, c. II, pág. 11.

42 Philosophical Rudiments, c III, I, 3. Leviathan, Of Man, c. XV.

43 Leviathan, of Man, c. XIV, Philosophical Rudiments.

44 Leviatan, Of Man, c. XIV y XV. Philosophical Rudiments, c. II, III, entero XVI. Cit. por Janet, op. cit.

45 Histoire de la Philosophie Morale et Politique.

46 De Civ. Lib., c. III, Lex naturalis eadem cum morali, XXIX, Leges natura sunt inmutabiles, XXVII, obligant in foro interiori.

47 De Civ. c. IV. 
moral natural se opone al derecho natural. El derecho nos autoriza a hacerlo todo. La moral nos impide todo.lo que es contrario a la paz. El uno y el otro descansan sobre un principio común: el deseo de la preservación.

En fin, las leyes naturales no son propiamente leyes sino teoremas. La verdadera ley es la palabra del jefe al cual todos estamos obligados a obedecer.

Así, para que la ley natural sea obligatoria es menester que se esté seguro de su ejecución. ${ }^{48}$ Esto lo asegura el poder civil. El poder civil no es el autor de la ley natural, mas es la condición indispensable para que se cumpla. $\mathrm{Y}$ esto se cumple en un hombre o asamblea. ${ }^{49}$ Por este pacto, la multitud se convierte en una persona. Esta persona es el Estado o la República. Es lo que Hobbes llama Leviatán o Dios mortal. El Estado puede ser definido:

Una persona autorizada en todas sus acciones por un cierto número de hombres, en virtud de un pacto reciproco, con el fin de usar del poder de todos para asegurar la paz y la defensa común.50

El poder civil es el poder absoluto.

Y de la anterior teoría fundamentada en el egoísmo tiene que derivar Hobbes, de una u otra manera, su ética y su teoría del orden social. Recordemos que en el estado de naturaleza no hay normas que rijan la vida del ser humano, ni siquiera la ley del más fuerte, ya que según Hobbes es muy poca la diferencia que hay entre las facultades y habilidades de unos y otros hombres, ya que "the weakest has strength enough to kill the strongest". Por naturaleza "every man has a right to everything, even to one body", y en este estado "every man is enemy to every man". En estas condiciones, ¿cuál es el lugar para el trabajo ordenado? ¿Para el conocimiento: ciencia, arte, filosofía o religión? ¿Cómo resolver el problema de una Sociedad? Sólo existe:

Continual fear and danger of violent death; and the life of man is solitary, poor, nasty, brutish and short $y$ force and fraud are in war the two cardinal virtues.51

El hombre se encuentra, pues, en el estado de naturaleza. Sólo a él le toca decidir acerca de lo justo y lo injusto; lo bueno y lo malo. Más aún, no se debe hablar, porque no tiene sentido, de justicia y de bondad.

Los hombres, por naturaleza, son iguales y ese miedo que se tienen los unos a los otros consiste, por un lado, en esa misma igualdad, y por otro en su recíproco deseo de hacerse daño. El hombre en estado de naturaleza es

48 Leviathan, c. XVII, Fhilosophical Rudiments.

49 Leviathan, Of Commonwealth, c. XVII. "Yo transmito a ese hombre o a esa asamblea", etcétera.

50 Leviathan, of Commonwealth, c. XVIII.

51 Leviathan, c. VI, XVI, c. XIV, X. 
una fiera con la voluntad dirigida hacia el daño de sus semejantes. Lo que ha de regir es la ley del más fuerte.

That men by nature are all equal. The cause of mutual fear consists partly in the natural equality of men, partly in their mutual will of hurting.52

All men in the state of nature have a desire and will to hurt... many seem at the same time have an appetite to the same thing; which yet very often they can neither enjoy in common, nor yet divide it; whence it follows that the strongest must have it, and who is strongest must be decided by the sword.53

En el estado de naturaleza, lo justo o lo injusto deben ser medidos no de acuerdo con las acciones, sino con el deseo y la conciencia de los agentes. Aquello que es hecho necesariamente y por amor a la paz, en vista de nuestra preservación, está bien hecho.

La ley natural coincide con la ley moral.

La ley civil no es más que la garantía de la natural. La ley natural es la regla por la cual nuestra razón comprende la necesidad de limitar y restringir el derecho natural, o sea, ese derecho de todos sobre todas las cosas y trae como resultado que ese estado de guerra sea constante. $Y$ es la ley la única que puede terminar con la relativización constante que hacen los hombres de los conceptos de bien y mal.

\section{3) Idea del Hombre}

El Leviathan está dividido en cuatro partes, que tratan del Hombre, el Estado, el Estado cristiano y el Reino de las Tinieblas.

El hombre es primero, ya que él es, a la vez, la materia y el artifice del gran Leviatán. ¿Qué es este hombre? En los comienzos mismos de la Introducción nos dice:

For seeing life is but a motion of Limbs, the beginning whereof is in some principall part within; why may we not say, that all Automata (Engines that move themselves by springs and wheeles as doth a watch) have an artificiall life? For what is the Heart, but a Spring; and the Nerves, but so many Strings; and the Joynts, but so many Wheeles, giving motion to the whole Body, such as was intended by the Artificer? 54

En la parte primera, dedicada al hombre, analiza las sensaciones, la imaginación, la consecuencia o serie de imaginaciones, el lenguaje, la razón y la ciencia, las pasiones, las virtudes, el poder, la estimación, la dignidad, la religión. Son especialmente interesantes el capítulo xIr, que trata de la condición natural del género humano, en lo que concierne a su felicidad y su miseria; el xIv, de la primera y segunda leyes naturales y de los contra-

52 Hobbes, Philosophical Rudiments, c. 1-3, pág. 6.

53 Idem, id., c. I. 4, pág. 7.

54 Hobbes, Leviathan, The introduction. 
tos, y el xv, de otras leyes de la naturaleza. Hobbes, como lo veremos en su ética, llega a la conclusión de que lo que nosotros deseamos es lo que llamamos bien, y lo que odiamos es lo que llamamos mal, y de estas nociones procede a describir la naturaleza del hombre, que no es otra cosa, al fin y al cabo, digámoslo de una vez, que un animal egoísta.

Tengamos presente que la psicología de Hobbes es materialista. Considerará no sólo al universo en su conjunto, sino al Estado y al hombre individual como un reloj o una máquina más o menos complicada, en la cual el corazón es el résorte, los nervios los hilos y las articulaciones las ruedas. $\mathrm{Y}$ en sus Philosophical Rudiments dice:

The faculty of human nature may be reduced into four kinds: bodily strength, experience, reason, passion.55 That the beninning of mutual society is from fear.56 All society therefore is either for gain or for glory; that is, not so much for love of our fellows, as for the love of ourselves. 57

Afirma Hobbes la igualdad de todos los hombres. Esta igualdad de los hombres la entiende no en un sentido político, sino físico y mental. La naturaleza ha hecho a los hombres iguales en sus facultades, tanto físicas como mentales. Quizá se encuentre un hombre más rápido de mente o fuerte de cuerpo, pero todo esto puede ser superado por secretas maquinaciones o por la unión con otros que sientan el mismo temor.

Nature hath made men so equall, in the faculties of body, and mind; as that though there bee found one man sometimes manifestly stronger in body, or of quicker mind than another; yet when all is reckoned together, the difference between man and man is not so considerablc, as that one man can thereupon claim to himselfe any benefit, to which another may not pretend, as well as he. For as to the strength of body, the weakest has strength enough to kill the strongest, either by secret machination, or by confederacy with others, that are in the same danger with himselfe.58

Dice Hobbes, al estudiar la naturaleza del hombre: así hallamos en la naturaleza del hombre tres causas principales de discordia: primera, la competencia; segunda, la desconfianza; tercera, la gloria.

La primera causa impulsa a los hombres a atacarse para lograr un beneficio; la segunda, para lograr seguridad; la tercera, para obtener reputación. La primera hace uso de la violencia para convertirse en dueña de las personas, mujeres, niños y ganados de otros hombres; la segunda, para defenderlos; la tercera recurre a la fuerza por motivos insignificantes, como una palabra, una sonrisa, una opinión distinta, como cualquier otro signo de subestimación, ya sea directamente en sus personas o de modo indirecto en

55 Hobbes, Philosophical Rudiments, c. I. Introduction.

56 Idem, id., c. I, 2.

57 Idem, id., c. I, 2, pág. 5 .

58 Hobbes, Leviathan, c. XIII. 
su decencia, en sus amigos, en su nación, en su profesión o en su apellido.59

El hombre, como producto de la naturaleza, es una criatura plena de pasión y ambiciosá de poder. A ese fin del poder se dirigen todas las pasiones humanas. El hombre vale tanto como pueda. Y ese poder es al que los hombres llaman dignidad. Satisfecho un deseo, surge otro. Y la felicidad humana consiste en satisfacer los deseos de manera gradual y progresiva.

So that in the first place, I put for a gencral inclination of all mankind, a perpetuall and restlesse desire of Power after power, that ceaseth onely in Death.60

For as Prometheus (which interpreted, is The prudent man), was bound to the hill Caucasus, a place of large prospect, where, an Eagle feeding on his liver, devoured in the day, as much as was repayred in the night: So that man, which looks too far before him, in the care of future time, hath his heart all the day long, gnawed on by feare of death, poverty, or other calamity; and has no repose, nor pause of his anxiety, but in sleep. 61

El hombre no es más que una cosa individual sobre la cual ejercen su acción las fuerzas exteriores. Singularmente los pensamientos de los hombres no son más que representaciones o apariencia de cierta cualidad o de otro accidente de un cuerpo exterior a nosotros, de lo que comúnmente llamamos objeto. Dicho objeto actúa sobre los ojos, oídos y otras partes del cuerpo humano, y por diversidad de actuación produce diversidad de apariencias.

El origen de todo ello es lo que llamamos sensación. En efecto: no existe ninguna concepción en el intelecto humano que antes no haya sido recibida, totalmente o en parte, por los órganos de los sentidos. Todo lo demás deriva de este elemento primordial. ${ }^{62}$

Todo conocimiento viene, pues, de la sensación, que no es más que un cierto movimiento de los órganos. La sensación, al pasar del cerebro al corazón, se convierte en placer o en dolor, y, según sea su objeto, en amor u odio. En realidad no existe más que la apariencia de las cosas en nuestra fantasia, "their appearance to us is fancy", aunque él le dé el nombre de decaying sense ("sensación decadente", ha traducido Manuel Sánchez Sarto). ${ }^{63}$ Este decaying sense, si queremos expresar la misma cosa (me refiero a la fantasía), lo llamamos imaginación, como ya dije antes; pero cuando queremos expresar ese decaimiento y significar que la sensación se atenúa, envejece y pasa, la llamamos memoria. Así, imaginación y memoria son una misma cosa que para diversas consideraciones posee, también, nombres diversos. ${ }^{64}$

59 Hobbes, Leviathan, c. XIII.

60 Hobbes, English Works, IV, pág. 75; citado por Pogson Smith, op. cit.

61 Idem, id., pág. 82.

a2 Leviathan, Of Man, c. I.

63 Hobbes, Leviatán, edición mexicana del Fondo de Cultura Económica.

04 Hobbes, Leviathan, Of Man, Part. I, c. I. 
Los hombres dicen que aman aquello que desean y que odian aquellas cosas por las cuales tienen aversión:

. That which men Desire, they are also sayd to Love: and to Hate those things, for which they have Aversion. So that Desire, and Love, are the same thing; save that by Desire, we always signifie the Absence of the Object; by Love, most commonly the Presence of the same. So also by Aversion, we signifie the Absence; and by Hate, the Presence of the Object.65

Muchos deseos y muchos temores combaten constantemente en nuestro espíritu. A este estado se le llama deliberación, y el último de sus deseos, que es en realidad el que le importa, es la voluntad.

When in the mind of man, Appetites, and Aversions, Hoppes, and Feares, concerning one and the same thing, arise alternately; and divers good and evill consequences of the doing, or omitting the thing propounded, come successively into our thoughts; so that sometimes we have an Appetite to it; sometimes an Aversion from it; sometirnes Hope to be able to do it; sometimes Despaire, or Feare to attempt it; the whole summe of Desires, Aversions, Hopes and Fears, continued till the thing be either done, or thought impossible, is that we call Deliberation...66

In Deliberation, the last Appetite or Aversion, inmediately adhering to the action, or to the omission thereof, is hat we call the will.

Deliberation is nothing else but a weighing, as it were in scales, the conveniences and inconveniences of the fact we are attempting; where that which is more weighty doth necessarily according to its inclination prevail with us.67

$\mathrm{Y}$ así como el último apetito en la deliberación se denomina voluntad, así la última opinión en busca de la verdad del pasado y del futuro se llama juicio o sentencia resolutiva y final de quien realiza el discurso. Y como la serie completa de los apetitos alternos en la cuestión de lo bueno y de lo malo se llama deliberación, así la serie completa de las opiniones que alternan en la cuestión de lo verdadero y de lo falso, se llama $d u d a{ }^{68}$

Tradicionalmente se ha pensado, dice Hobbes, en el hombre como una criatura racional, pero es algo más. Es un ser pleno de actividad. Esa influencia del ambiente exterior a que nos hemos referido antes, provoca en el ser humano reacciones hacia aquello que ayuda la actividad vital, "vital motion". El placer será un movimiento que ayuda la acción vital y el dolor algo que la obstaculiza. Se observará de inmediato que no hay conexión lógica con su teoría de que los apetitos o deseos tienden siempre como objetivo al placer o a evitar el dolor. Pero no olvidemos que es un filósofo materialista tratando de presentar un sistema de psicología, y que necesariamente dará importancia a esos impulsos que surgen de los deseos del cuerpo, cuyo objetivo obvio es la preservación del organismo del agente, y esto,

65 Hobbes, Leviathan, of Man, Part. I, c. VI, pág. 4o.

66 Hobbes, Leviathan, Of Man, Part. I, c. VI, pág. 46.

67 Hobbes, Philosophical Rudiments, c. XIII, 16, pág. 180.

68 Hobbes, Leviathan, Of Man, Part. I, C. VI. 
unido a su deseo filósofico de simplificar, le llevará a la conclusión de que en todo impulso humano hay una preocupación egoista del hombre.

$\mathrm{Y}$ eso es el hombre para Hobbes: un ser cuyos apetitos y deseos están materialmente dirigidos ya sea a la preservación de su vida o a la búsqueda e intensificación del placer.

\section{4) Idea de la Sociedad}

Como bien advierte Wundt en su Ética, lo primero que trata Hobbes es de destruir lo afirmado por Aristóteles y enseñado por la escolástica: "El hombre es un animal racional nacido para la sociedad." A veces llega a referirse a Aristóteles como al maestro más pernicioso que jamás haya existido. Dice Hobbes que, a su juicio, difícilmente podrá existir cosa tan absurda como la que ahora se denomina metafísica aristotélica; ni nada tan contrario al gobierno como gran parte de lo que dijo en su Politica ni nada más ignorante que gran parte de su Ética.69

Con palabras no menos duras, que no con argumentos convincentes, se refiere a la escolástica. No olvidemos que entre los principios materialistas de su metafísica y las consecuencias en el orden político y moral está el quid de su filosofía. Y él necesitaba destruir todas las afirmaciones tradicionales para poder asentar de manera lógica y precisa su principio del estado de guerra, que es, en realidad, la base de toda su doctrina. Es decir, que el hombre no es social por naturaleza, sino por accidente, por necesidad. Lo que buscamos en los demás hombres no es compañia, sino nuestro propio y único interés. Nosotros deseamos obtener bienes o ventajas, ya sean de orden físico o espiritual.70 Queremos recordar el ejemplo citado una y otra vez y con el cual trata Hobbes de probar que nos dejamos llevar por bellas palabras, pero que la realidad es otra. Hobbes propone un experimento: que se considere el hombre a sí mismo. Verá que cuando emprende una jornada procura armas y trata de ir bien acompañado; cuando va a dormir cierra las puertas y hasta cuando se halla en su propia casa echa la llave a sus arcas. $\mathrm{Y}$ eso a pesar de que sabe que existe un gobierno que le protege. ¿No es esto acusar a la humanidad con los actos, por mucho que luego trate de alabársela con palabras?

It may seem strange to some man, that has not well weighed these things; that Nature should thus dissociate, and render men apt to invade, and destroy one another; and he may therefore, not trusting to this Inference, made from the Passions, desire perhaps to have the same confirmed by Experience. Let him therefore consider with himselfe, when taking a journey, he armes himselfe, and seeks to go well accompanied; when going to sleep, he locks his dores; when even in his house he locks his chests; and this when he knowes there bee Lawes, and publike Officers, armed, to-

69 Hobbes, Leviathan, Part. IV, c. XLVI.

70 Hobbes, Philosophical Rudiments, Preface, c. I, II. 
revenge all injuries shall bee done him; what opinion he has of his fellow subjects, when he rides armed; of his fellow Citizens, when he locks his dores; and of his children, and servants, when he locks his chests. Does he not there as much accuse mankind by his actions, as $I$ do by my words? But neither of us accuse mans nature in it. The Desires, and other Passions of man, are in themselves no Sin. No more are the Actions, that proceed from those Passions, till they know a Law that forbids them: which till Lawes be made they cannot know: nor can any Law be made, till they have agreed upon the Person that shall make it.71

Se puede ver, tanto en el Leviathan como en De Cive, que para formular su teoría del Estado Hobbes parte de la definición tradicional del derecho natural, según la cual debe darse a cada uno lo suyo. Pero, ¿qué quiere decir mio?; ¿y tuyo?

Antes de toda sociedad civil, repetirá Hobbes, no existe lo justo ni lo injusto, lo tuyo ni lo mío. En esta guerra de todos contra todos se da una consecuencia: que nada puede ser injusto. Las nociones de derecho e ilegalidad, justicia e injusticia están fuera de lugar. Donde no hay poder común, la ley no existe: donde no hay ley, no hay justicia. No hay distinción entre tuyo y mío; sólo pertenece a cada uno lo que puede tomar, y sólo en tanto que puede conservarlo. Las pasiones que inclinan a los hombres a la paz y a la asociación son el temor a la muerte, el deseo de las cosas que son necesarias para una vida confortable y la esperanza de obtenerlas por medio del trabajo. ${ }^{72}$ No se puede hablar de justicia e injusticia como cosas que pertenezcan al hombre en tanto hombre, sino en tanto ciudadano. "Justicia e injusticia no son facultades ni del cuerpo ni del espíritu. Si lo fueran podrían darse en un hombre que estuviera solo en el mundo, lo mismo que se dan sus sensaciones y pasiones. Son, aquéllas, cualidades que se refieren al hombre en sociedad, no en estado solitario." 73

El hombre oscila, pues, entre su conservación, la conservación de su vida y el terrible temor a la muerte. Entre estos dos extremos se angustia y vive sufriendo, esperando el final. Por otra parte, el estado de naturaleza en el que nace el hombre es el estado de lucha de uno contra todos. El estado de naturaleza es el estado más desdichado del hombre. Homo homini lupus. Hay que encontrar una salida hacia la seguridad. La solución es salir del estado de naturaleza en el que el hombre es lobo del hombre, para obtener la seguridad y la paz. Y es así como surge en él la idea de sociedad. El Estado, a su vez, ha de tener una cabeza o jefe cuyo poder será ilimitado, ya que en él está representado el poder de todos los asociados reunidos. Él será la conciencia pública acatada por todos. Propiedad, libertad, sociedad, etc., existirán mientras el Estado las tolere. ${ }^{74}$

71 Hobbes, Leviathan, Part. I. c. XIII.

72 Leviathan, Of Man, cap. XIII.

73 Ibid.

74 Hobbes, Philosophical Rudiments, I, c. I. 
Afirma Windelband ${ }^{75}$ que: “...el fundamento de la teoría del contrato reposa en Hobbes en motivos más generales. Al concebirse la vida política y social partiendo de la naturaleza humana, encuentra el filósofo inglés el carácter esencialísimo de ella en el instinto de conservación o el egoísmo, simple y evidente principio explicativo de toda la vida volitiva. Con ello refieren la metafísica materialista y la psicología sensualista este instinto de conservación, según su esencia, al mantenimiento y elevación de la existencia sensible del individuo. Todos los demás objetivos de la voluntad no tendrían otro valor que el de medios para la realización de aquel supremo y comprensivo designio. Con arreglo a este principio no debe tener el hombre como esencia natural otra norma de valoración que la del provecho o el daño, el estímulo o el refrenamiento; la distinción de lo bueno y de lo malo, de lo justo y de lo injusto no se funda en la naturaleza del individuo, sino en puntos de vista sociales, allí donde se toma como pauta de valoración el interés colectivo en vez del particular. De esta guisa se convierte el egoísmo en el principio de toda la filosofía práctica; pues si el instinto de conservación del individuo debe ser limitado y enmendado por el mandato del Estado, se ve en este mismo Estado la más ingeniosa y perfecta de todas las instituciones que ha encontrado el egoísmo para lograr y asegurar su satisfacción. El estado de naturaleza en que el egoísmo de uno se halla en oposición del egoísmo de otro, es la lucha de todos: para escapar de él ha sido creado el Estado, como un convenio de mutua garantía, a fin de promover la paz entre sus miembros".

Como dice en la segunda parte del Leviathan, al tratar del Estado ${ }^{76}$ como la causa final, fin o designio de los hombres (que, naturalmente, aman la libertad y el dominio sobre los demás), al introducir esta restricción sobre sí mismos (en la que los vemos vivir formando Estados), los hombres forman el Estado para el cuidado de su propia conservación y, por añadidura, el logro de una vida más armónica; es decir, el deseo de abandonar esa miserable condición de guerra que, tal como hemos manifestado, es consecuencia de las pasiones naturales de los hombres, cuando no existe poder visible que los tenga a raya y los sujete, por temor al castigo, a la realización de sus pactos y a la observancia de las leyes de naturaleza explicadas en los capítulos xIV y xv.

\section{5) Concepción metafísica}

La actitud de Hobbes es francamente materialista. Partiendo de una actitud empírica desarrolla una filosofía materialista. Insiste en un racionalismo, pero su universo racional ha de ser deducido de un solo y simple principio. Aquí su diferencia con Descartes. El movimiento es la única realidad, y toda otra cosa no es más que fantasía y creación de nuestras mentes. Como ad-

75 Historia de la filosofia, tomo "Filosofía moderna".

76 Cap. XVII. 
vierte Sorley, ${ }^{77}$ Hobbes, que habla formulado una teoría mecánica del universo físico, ni siquiera conocía bien una de estas teorías, como, por ejemplo, la de Descartes.

Pero Hobbes fue mucho más lejos, y presenta una teoría más audaz aunque imposible. Descartes restringe el mecanismo del mundo exterior y mantiene la independencia de la existencia mental. La mente es lo más cierto. Hobbes no limita la aplicación de su nueva idea. Él pensó que podía tranquilamente pasar de los movimientos exteriores a "los movimientos internos de los hombres", y de allí a la formulación de una teoría política y una teorfa moral. Esto es lo que él exactamente nos dice. Insistimos con Sorley en que su actitud metafísica (materialismo mecanicista) y su psicología son la raíz misma de sus conclusiones éticas y políticas. Es alli donde se debe concentrar el ataque a las deshumanizadoras tesis de Hobbes.

Las transiciones de un movimiento exterior a uno interior, para utilizar el lenguaje de Hobbes, no se pueden llevar a cabo de manera lógica. Él mismo, más tarde, encuentra la dificultad. Pero más que un filósofo fue un político, que trataba de acomodar y explicar un determinado momento histórico, y encontró que su teoría sólo podía sostenerse sobre la base de una concepción materialista del universo. El carácter externo y mecánico de su teoría política es el signo más evidente de su carencia de realidad. La crítica a su materialismo mecanicista y a su idea del hombre fue intentada por los moralistas ingleses inmediatamente posteriores. Algunos de los llamados platonistas de Cambridge, especialmente Cudworth y Moore.

\section{6) Etica}

a) La conciencia. Hobbes, una y otra vez, niega la realidad de la conciencia, y trata de explicarla como una adquisición, como un producto de la experiencia. Afirma que no tenemos ninguna facultad moral que pueda, intuitivamente, distinguir entre bien y mal. Nuestro conocimiento de lo moral, como todo otro conocimiento, lo hemos adquirido a través de la experiencia:

It is either science or opinion which we commonly mean by the word conscience; for men say that such a thing is true in upon their conscience; which they never do when they think it doubtful, and therefore they know or think they know it to be true. But men when they say things upon their conscience, are not therefore presumed certainly to know the truth of what they say: it remained then that word is used by them that have an opinion, not only of the truth of a thing, but also of their knowledge of it; to which the truth of the proposition is consequent. I therefore define to be opinion of evidence. 78

Y en su trabajo donde trata el tema de la libertad y necesidad, nos dice:

7 History of English Philosophy, pág. 61.

78 Hobbes, On Human Nature, c. VI-8. 
I conceive that when a man deliberates wheter he shall do a thing or not do it, he does nothing else but consider whether it be better for himself to do it or not to do it.79

b) Bien y mal; justo $e$ injusto. El estudio del bien y del mal, de lo justo y de lo injusto se concretará, para Hobbes, al estudio de lo bueno y lo malo en las conversaciones y sociedades de la humanidad. Será algo puramente convencional. Mal y bien, justicia e injusticia, serán únicamente los nombres tras los cuales se agazapan hipócritamente nuestros deseos y nuestras aversiones. $\mathrm{Y}$ esos nombres, esas palabras, no son más que "the money of fools". Además, los deseos y aversiones cambian constantemente y de acuerdo con los temperamentos, costumbres y doctrinas de hombres que son y tienen que ser, por su misma estructura, diferentes, tanto en las sensaciones que reciben de los sentidos como en aquello que se conforma o no con la razón. Es lo que nos dice en el Leviathan:

For Morall Philosophy is nothing else but the Science of what is Good, and Evill, in the conversation, and Society of man-kind. Good, and Evill, are names that signifie our Appetites, and Aversions; which in different tempers, customes, and doctrines of men, are different: And divers men, differ not onley in their Judgement, on the senses of what is pleasant, and unpleasant to the tast, smell, hearing, touch, and sight; but also of what is conformable, or disagreeable to Reason, in the actions of common life. 80

El objeto natural de los deseos del hombre es aquello que le es agradable, lo que le place; lo que tememos u odiamos es nuestro mal: "Displeasure is the appearance or sense of evil". Lo que nosotros deseamos es nuestro bien: "Pleasure is the appearance or sense of good." Bien y mal no son, pues, otra cosa que placer y dolor:

Such is the nature of man, that every one calls that good which he desires and evil which he eschews. And therefore through the diversity of our affections it happens, that one counts that good which another count evil; and the same man what now he estemed for good he inmediately after looks as an evil: and the same thing which he calls good in himself, he terms evil in another; for we all measure good and evil by the pleasure or pain we either feel at present or expect hereafter.81

Y que el amor sea deseo del bien y el odio aversión del mal son cosas tan ineludibles y necesarias como que la piedra caiga hacia la tierra o uno más uno sea igual a dos. Nada de lo que es necesario puede estar contra la razón y, como consecuencia, todo lo que está contra la razón es justo y legítimo; es la justicia, es el derecho. Tenemos el derecho de seguir el bien y evitar el

79 Hobbes, On Liberty and Necessity.

80 Hobbes, Leviathan, c. XV.

81 Hobbes, Leviathan, c. XIX-17, pág. 196. 
mal. La conservación será nuestro sumo bien. La muerte el mal más terrible y del que debemos precavernos. ${ }^{82}$

Pero todo lo anterior nos llevará a otra consecuencia. Si todas nuestras acciones voluntarias emanan de las diversas opiniones que nosotros tenemos acerca del bien y del mal, de lo justo y lo injusto, entonces será el Estado quien está encargado de velar por las acciones de los asociados y a quien tocará, inevitablemente, investigar las opiniones de esos mismos asociados. El Estado está encargado de la paz y la defensa común y no puede permitir, por tanto, que se propaguen y enseñen doctrinas que propugnen la desobediencia a ese mismo Estado. $Y$ al mismo tiempo ha de preocuparse por propagar aquellas doctrinas que aseguren una mayor obediencia de los asociados. Ya vemos aquí un concepto de la propaganda al servicio del Estado, como fijador de verdades y que ha desempeñado un papel tan preponderante en la mentalidad moderna. ${ }^{83}$

The civil laws were the rulers of good and evil, just and unjust, honest and dishonest; that therefore what the legislator commands, must be held for good, and what he forbids for evil.84

It belongs to kings to discern between good and evil, wicked are those though usual, sayings, that he only is a king who does righteously, and that kings must not be obeyed unless they command us just things; and many other such like. Before there was any government $j u s t$ and unjust had no being, their nature only being relative to some command; and every action in its own nature is indifferent; that it becomes just or unjust, proceeds from the right of the magistrate. Legitimate kings therefore make the things they command just, by commanding them and those which they forbid, unjust, by forbidding them. But private men, while they assume to themselves the knowledge of good and evil desire to be even as kings; which cannot be with the safcty of the Commonwealth. 85

c) El interés como consejero moral. El fin principal de nuestra existencia, en el pensamiento de Hobbes, es, como ya vimos antes, la conservación y desarrollo de la vida. Los medios para conseguir este fin serán la legitimación del derecho de emplear todos los medios posibles para la conservación de nuestra vida. ${ }^{86}$ Pero esto nos llevará a una segunda consecuencia, y es que cada uno es juez de los medios que crea necesarios para su conservación. ${ }^{87}$ Ahora bien, si yo tengo el derecho de defender, preservar y desarrollar mi vida, puedo utilizar todos los medios posibles, y soy el único juez de tales medios, resultará que emplearé todo para mi conservación y que el consejero moral

82 Hobbes, Philosophical Rudiments, c. I, VII, pág. 8.

83 Ver sobre el particular el interesante trabajo de J. $\mathrm{M}^{a}$ Sánchez de Muniain Filosofia de la propaganda (curso monográfico dictado en la Universidad de Madrid, 1951-52).

84 Hobbes, Philosophical Rudiments, c. VI-9.

85 Hobbes, Philosophical Rudiments, c. XII-1, págs. 149-150.

86 Idem., id. VII.

87 Hobbes, Philosophical Rudiments, IX. 
de tal juez será única y sencillamente el interés. La medida de mi derecho y, por ende, la medida de mi ética y de mi moral, será la utilidad.8 Claro que esto nos va a llevar a otra consecuencia. Yo no soy el único que vivo. No soy un Robinsón. Hay otros seres vivientes a mi alrededor. ¿Cuál es la posición de esos otros seres? ¿Cuál es mi posición? ¿Cuál es la relación entre unos y otros? Hobbes dirá: "Todos los hombres son iguales",89 pero cuidémonos y pongamos un poco de atención a esa igualdad de los hombres que proclama Hobbes. Todos los hombres tienen un derecho absoluto sobrè todas las cosas y todos un igual poder, pero, con esta afirmación, podemos ver inmediatamente que este derecho de todos sobre todas las cosas carece de significado real. ¿Qué importa decir que tal cosa es mía si todos pueden decir otro tanto? ${ }^{80}$ De esta igualdad de naturaleza y de esta igualdad de derechos entre todos los hombres nace la guerra. Los hombres, al tener los mismos deseos, se vuelven enemigos. El estado de naturaleza es el estado de guerra de todos contra todos. $\mathrm{Y}$ aqú está el principio original y esencial de la moral y la ética de Hobbes.

d) La Justicia. Según Hobbes no tiene sentido hablar de justicia en ese estado de naturaleza que ya hemos tratado de describir. Se habla de justicia cuando la sociedad está ya constituida. $Y$, ¿qué es entonces la justicia? Justo e injusto, lo mismo que justicia e injusticia, son términos que se prestan a equívoco. $\mathrm{Y}$ es menester distinguir cuándo estos términos se aplican a las personas y cuándo a las acciones.

These words just and unjust as also justice and injustice are equivocal; for they signify one thing when they are atributed to persons another when to actions. When they are atributed to actions just signifies as much as what is done with right, and unjust as what is done with injury. He who had done some just thing is not therefore said to be a just but guiltless; and he that had done some unjust thing, we do not therefore say he is an unjust but guilty man. But when the words are applied to persons to be just signifies as much as to be delighted in just dealing, to study how to do righteousness, or to endeavour in all things to do that which is just; and to be unjust is to neglect righteous dealing, or to think it is to be meassured not according to my contract, but some present benefit.91

La justicia de que nos habla el Leviathan está, paradójicamente, vacía de todo contenido ético. Su idea de la justicia hemos de buscarla en su teoría de los pactos o convenciones o contratos. Antes del pacto, no existe ni lo tuyo ni lo mío. No hay justicia ni injusticia. De acuerdo con nuestras normas, justo es dar a cada uno lo suyo. Pero esa distinción de lo mío y lo tuyo no comienza sino con la iniciación del gobierno civil; será, por tanto, en esa sociedad civil

\footnotetext{
88 Idem., id.

89 Philosophical Rudiments, III, y Leviathan, Of Man, c. XIII.

80 Philosophical Rudiments, 1-2 y 3.

91 Philosophical Rudiments, c. III, 5, pág. 32 .
} 
en donde hay que buscar el significado y sentido de la justicia. Y la justicia no es más que la observancia de las convenciones. ${ }^{92}$

Before the yoke of civil society undertaken, no man had any proper right; all things were common to all men. Tell me therefore how gottest thou this propriety but from the magistrate? How got the magistrate it, but that every man transferred his right on him? And thou therefore hast also given up thy right to him. Thy dominion therefore and propriety is just so much as he will, and shall last as long as he pleases.83

Entonces el derecho de propiedad, lo tuyo y lo mío en que ha de basarse la justicia, no es más que una concesión del gobierno civil. ¿De dónde es que hemos obtenido nuestra propiedad si no es del Estado? dirá Hobbes. Por tanto, la base de ese derecho de propiedad está totalmente subordinada al Estado. ${ }^{94}$

e) La Caridad. La caridad, nos dice Hobbes, es el placer que el hombre siente al tener su propia sensación de poder, la capacidad de ayudar a los otros $y$, por otra parte, la sensación de fariseo de que no es como los demás.

There can be no greater arguments to a man of his own power, that to find himselt able not only to accomplish his own desires but also to assist men in theirs; and this is that conception wherein consisteth charity. 95

Cuando el hombre da, lo hace siempre guiado por un interés, ya que el dar es una acción voluntaria y en todo acto voluntario lo que el hombre persigue es su propio bien:

No man giveth but whith intention of good to himself, because gift is voluntary; and of all voluntary acts, the object to every man is to his own good.96

Como vemos, no distingue Hobbes entre búsqueda instintiva y búsqueda deliberada de placer. La piedad que pueda el hombre sentir ocasionalmente por sus semejantes no es más que un resultado de imaginarse que esa calamidad de que se apiada le pueda ocurrir a él.

f) Idea de la libertad. Es interesante la noción de libertad que desarrolla Hobbes. Se puede afirmar que hay libertad cuando no encontramos obstáculos al desarrollo de nuestros movimientos a a la realización de nuestras intenciones y deseos:

Liberty is an absence or the lets and hindrances of motion. The more ways a man may move himself the more liberty he hath. 97

92 Philosophical Rudiments, c. III, IV y V; y Leviathan, c. XV. Of Man.

93 Philosophical Rudiments, c. XII-7, pág. 157.

94 Philosophical Rudiments, c. VI, XV, c. XII, VII; Leviathan, c. XVIII.

95 On Human Nature, c. IX-17.

96 Hobbes, Leviathan, Part. I, c. XV.

97 Hobbes, Philosophical Rudiments, c. IX-9, 120. 
Pero los obstáculos pueden provenir o de la naturaleza de las cosas o de la ley. No puedo alcanzar una estrella porque está muy lejana, o no puedo matar a una persona sin que sobre mí caiga el peso de la ley. Se oponen a nuestra libertad la naturaleza y la ley. Pero cuando los obstáculos provienen de la naturaleza, lo que le falta al hombre no es libertad sino poder. Cuando provienen de la ley, el hombre es libre en la medida en que sus acciones son o no prohibidas. Sin embargo, la ley no obstaculiza todas nuestras acciones. Hay un número incalculable de acciones que no están prescritas por ley alguna: que yo puedo hacer o dejar de hacer. $\mathrm{Y}$ en el círculo de estas acciones el hombre es libre. La libertad de las democracias es una falsa libertad: en esa clase de gobierno la ciudad es libre, y no los ciudadanos. Es falso, comenta Janet, ${ }^{98}$ decir que sólo se es libre en una democracia. Puede ser que una monarquía permita muchas más acciones que una república. Es el número de acciones libres lo que constituye la medida de la libertad.

Los súbditos han de obedecer al soberano, pero hay excepciones a esta regla. Sólo se está obligado a obedecer en tanto que el poder del gobernante puede brindar protección. Hobbes llega a reconocer al pueblo el derecho de someterse a un vencedor, si el soberano es apresado.

g) La religión. Si la moral, como el derecho, es producto de la reflexión, de la conveniencia y del cálculo social, tendremos como lógica consecuencia que ningún mandato divino o humano la podrá superar ni contradecir. En este caso, ¿cuál es el papel de la religión? Por el momento, podemos afirmar que en el pensamiento de Hobbes la religión ha de quedar subordinada y obediente al Estado. La religión sólo será aceptable en cuanto el Estado la reconozca como conveniente. El ciudadano se halla libre ante la autoridad de la Iglesia. Reconoce Hobbes en De Cive ${ }^{99}$ la posibilidad de un reino de Dios fundado como el Estado sobre el poder del jefe y el temor de los súbditos. Como todo rey, Dios ha de ser honrado y este honor rendido a Dios es o natural o profético, sea que esté fundado sobre la sola razón o sobre la revelación expresa de Dios. Pero es menester, dice Hobbes, distinguir lo temporal de lo espiritual. ${ }^{100}$ A lo temporal le tocará decidir lo que es justo o injusto, resolver controversias acerca de los medios de preservar la paz y la defensa pública, etc. A lo espiritual toca únicamente lo relacionado con la fe y la salvación. Pero claro está que cuando los conflictos se presenten, tocará a una investigación racional y pertenece al derecho temporal señalar la frontera entre lo temporal y lo espiritual.

A distinction of things temporal from spiritual. The definition and determination of what is just and unjust, the cognizance of all controversies about the means of peace and public defense, and the examinations of doctrines and books in all man.

98 Histoire de la Philosophie Morale.

99 Philosopihical Rudiments, c. XV.

100 Idem., id. 
ner of rational science depends upon the temporal rights; but those which are mysteries of faith depending on Christ's word and authority only, their judgements belong to spiritual right. But it is reason's inquisition and pertains to temporal right to define what is spiritual and what temporal; because our Saviour hath not made that distinction.101

\section{Como dice Wundt: 102}

El punto de vista más radical de la política realista lo toma Hobbes a causa de su indiferentismo religioso: la religión es cosa privada y sólo tiene validez pública aquella de que hace profesión de fe el Estado. Con ello presenta este pensador la teoría filosófica del histórico 'Cujus regio illius religio'.

La religión es un engranaje más de la maquinaria política. Es la posición que toma todo totalitarismo, sea de izquierda o derecha.

No consideramos, por ahora, sus ataques al catolicismo en la última parte del Leviathan. Esos ataques están empapados de pasión política y, en el fondo, no son más que el temor constante, manifestado por Hobbes, una y otra vez, del peligro que entraña un cristianismo auténtico para su sociedad de autómatas.

h) El utilitarismo. Las opiniones de Hobbes en torno a la esencia y origen de la virtud han sido adoptadas por cierto sin grandes variantes por un gran sector de la corriente utilitarista. De acuerdo con estos pensadores, estamos guiados únicamente por nuestros propios intereses. Dice Hobbes:

I conceive that when a man deliberates whether he shall do a thing or not do it, he does nothing else but consider whether it be better for himself to do it or not to do it.103

\section{Dice Bentham en sus "Principios de Moral":}

By the principle of utility is meant that principle which approves or desapproves of every action whatsoever, according to the tendency which it appears to have to augment or diminish the happines of the party whose interest is in question.104

Sobre este particular son interesantes las comparaciones que hace Lecky. ${ }^{105}$ Dice Fiobbes:

For Morall Philosophy is nothing else but the Science of what is Good, and Evill, in the conversation, and Society of man-kind. Good, and Evill, are names that signifie our Appetites, and Aversions; which in different tempers, customes, and doctrines of men, are different.106

101 Philosophical Rudiments, c. XVII-14, pág. 270.

102 Ética, pág. 15 o.

103 On Liberty and Necessity.

104 Principles of Morals and Legislation, c. I.

105 History of European Moral. Comparar el Leviathan, Parte C, cap. XVI, con la Deontology de Bentham, vol. II, pág. 132.

106 Hobbes, Leviathan, Part. I, c. XV, pág. 122. 
From whence arise Disputes, Controversies, and at last War. And therefore so long a man is in the condition of meer Nature (which is a condition of War), as private Appetite is the measure of Good, and Evill: and consequently all men agree on this, that Peace is Good, and therefore also the way, or means of Peace, which (as I have shewed before) are Justice, Gratitude, Modesty, Equity, Mercy, \& the rest of the Laws of Nature, are good; that is to say Morall Vertuses; and their contrarie Vices, Evill,107

Es la antigua equiparación de Virtud con Interés, pero que llega a un sentido matemático casi comercial entre estos moralistas ingleses; nos referimos a los de tendencia utilitarista, poco inclinados a darle sitio a los valores religiosos; la virtud es una juiciosa búsqueda del placer. La virtud es una rama de la prudencia. Es un retorno a las cuatro leyes de Epicuro. Vicio no es más que imprudencia y mal cálculo. Como dice Bentham:

Vice may be defined to be a miscalculation of chances, a mistake in estimating the value of pleasure and pain. It is false moral arithmetic 108

Weight pains, weight pleasures, and as the balance stands will stand the question of right and wrong.109

\section{7) Comentario}

No creemos que para una crítica de las doctrinas de Hobbes sea necesario llegar a los extremos de Sorley cuando recuerda que la madre de Hobbes lo dio a luz prematuramente, plena de terror por el avance de la Armada Española. El mismo Hobbes dice refiriéndose a su madre, "she brought forth twins: myself and Fear". Se puede reconocer, sin embargo, que luego del terror de la invasión, Hobbes vivió una época de guerra civil y gobiernos inestables. De ahí su convicción de que la búsqueda de paz y seguridad son leyes fundamentales de la naturaleza, y llega a ser, en lo personal, como él mismo se califica "a man of feminine courage": el primero en huir ante el terror de la guerra civil en su país, se apresura a regresar cuando el gobierno de Francia, donde se había refugiado, parece ofrecerle poca protección. Se citan una y otra vez las palabras de Hobbes a Edward Hyde, más tarde conde de Clarendon, de que publicaba el Leviathan, porque "tenía intenciones de volver a casa". En su Philosophical Rudiments nos dice:

It so happened in the interim, that my country, some few years before the civil wars did rage, was boiling hot with questions concerning the rights of dominion and the obedience due from subjects, the true forerunners of an approaching war.110

107 Hobbes, Leviathan, Part. I, c. XVI, pág. 122.

108 Bentham, Deontology, vol. I, pág, 191.

109 Deontology, vol. I, pág. 137.

110 Op. cit., Preface to the Reader, XX. 
No es éste el momento para hacer una crítica detallada a Hobbes, pues ello desbordaría nuestro espacio. Sus mismos contemporáneos le refutaron con vigor. Es poca la originalidad en las afirmaciones éticas de Hobbes. Se trata de un epicureísmo llevado a los extremos, sin tener siquiera el atenuante de un perfeccionamiento o de una mejor o más clara presentación. Su totalitarismo no está fundado, como en los modernos totalitarismos, en una exaltación mística, ni presentado como un fin en sí mismo, sino que se basa en consideraciones de egoísmo práctico. Su teoría ética determinará negativamente todo el curso de la especulación ética en Inglaterra por cien años: Cumberland, Cudworth, Moore, Clarke y, en cierto sentido, Shaftesbury y Butler son, antes que nada, críticos implacables y oponentes de Hobbes.

Creemos nosotros que la mejor refutación a la teoría ética de Hobbes se encuentra en su exposición detallada. Repugna tanto a los más íntimos sen. timientos de humanidad una teoría que pretende reducir al hombre a un robot sin alma y sin personalidad, al servicio de ese Deus Mortalis que es el Estado.

Los errores fundamentales del sistema ético de Hobbes no le son peculiares, pero hay que reconocer que es él quien los ha presentado con mayor precisión y audacia.

Si el hombre fuera tan anárquico y egoísta como lo presenta la concepción antropológica de Hobbes, entonces, ciertamente, su concepción moral y política sería correcta. Pero si su punto de vista acerca del hombre está equivocado, entonces toda esa enorme fábrica levantada por Hobbes se resquebraja hasta sus cimientos y cae ruidosamente.

Acabamos de observar su actitud metafísica que lo lleva a grandes contradicciones. Advierte Mackintosh ${ }^{111}$ que Hobbes toma las afirmaciones más adversas a las opiniones sostenidas por la humanidad y las más chocantes y odiosas a sus sentimientos, y las introduce en el curso de sus argumentos con una frialdad matemática. Las presenta como conclusiones demostradas, sin dignarse explicar cómo es que todos los demás creen lo contrario de sus absurdos y, más aún, ni siquiera reconoce cuán opuestas están sus opiniones a los más antiguos y universales juicios del conocimiento humano. Pero la verdad para Hobbes no era algo que se encontraba al final de una investigación. La verdad es algo que se hace. Que los hombres se pongan de acuerdo acerca de cuál es la verdad, y ésa será la verdad. Terminamos con la afirmación de Pogson Smith, "Hobbes fue un filósofo que no tuvo fe en la verdad".

Universidad de Panamá.

Diego Domínguez Caballero 


\section{Bibliografia 1}

Sir W. Molesworth publica una edición completa de los trabajos de Hobbes Latin Works, 5 vols., English Works, 11 vols., 1839-45. Elements of Law y Behemonth fueron publicadas de una revisión de los manuscritos por F. Tönnies, en 1889. Leviathan, ediciones en Oxford, 1881 y 1909, y el texto ed. por A. E. Walter, Cambridge, 1904. Nosotros en nuestro trabajo hemos utilizado la edición de Oxford.

\section{Algunos de los trabajos acerca de Hobbes}

G. Lyon, La philosophie de Hobbes, 1893.

R. Mondolfo, La morale di T. Hobbes, 1903.

G. C. Robertson, Hobbes, 1886.

Sir L. Stephen, Hobbes, 1904.

G. Tarantino, Saggio sulle idee morali e politiche di T. Hobbes, 1900.

T. E. Taylor, Hobbes, 1909.

F. Tönnies, Hobbes, Leben und Lehre. 1896; 2a ed., 1912. (Traducción española en la Revista de Occidente).

J. Laird, Hobbes, 1934.

L. Strauss, Political Philosophy of Hobbes.

H. W. Moser, Thomas Hobbes.

C. Schmith, Der Leviathan in der Staatslehre des T. H. Hobbes (1938).

A. Levi, La filosofia di T. Hobbes (1929).

F. Braude, Thomas Hobbes Mechanical Conception of Nature (1921), trad. inglesa, 1928.

1 Este es uno de los capítulos de mi trabajo inédito Principios de la ética inglesa, que preparo para su publicación y donde incluyo una extensa bibliografía que, en estos momentos, sólo recargaría la extensión del presente trabajo. 